REPERTÓRIO

LIVRE

\title{
CONSIDERATIONS ON PAIN AND SUFFERING IN VESTANDPAGE'S PERFORMANCE ART
}

CONSIDERACIONES SOBRE DOLOR Y SUFRIMIENTO EN LA PERFORMANCE ART DE VESTANDPAGE

ANDREA PAGNES (VESTANDPAGE)

FELIPE HENRIQUE MONTEIRO OLIVEIRA

AMBER ROSE ELLIS

AISHA RYANNON PAGNES

PAGNES (VESTANDPAGE), Andrea; OLIVEIRA, Felipe Henrique Monteiro; ELLIS, Amber Rose; PAGNES, Aisha Ryannon.

Considerations on pain and suffering in VestAndPage's performance art.

Repertório, Salvador, ano 22, n. 32, p. 266-300, 2019.1 


\begin{abstract}
This text is formed from a series of detailed conversations with Andrea Pagnes of performance art duo VestAndPage (Italian artist Andrea Pagnes and German artist Verena Stenke) on the questions of pain, suffering and blood rituals in their performances. VestAndPage perform extreme physical acts in constrictive physical situations not to glorify pain, but as possibilities for a poetic encounter with suffering as a source of creativity, thus to liberate aesthetics from the justification of sacrifice. Drawing from their personal life experience, they translate their wounds into performative actions to seek authenticity and to speak about existential concerns belonging to humanity, the individual and society.
\end{abstract}

RESUMO

Este tex to é formado a partir de uma série de conversas detalhadas com Andrea Pagnes, do duo de performance arte VestAndPage (artista italiano Andrea Pagnes e artista alemã Verena Stenke) sobre as questões de dor, sofrimento e rituais de sangue em suas performances. O VestAndPage realiza atos físicos extremos em situações físicas constritivas, não para glorificar a dor, mas como possibilidades de um encontro poético com o sofrimento como fonte de criatividade, para assim libertar a estética da justificação do sacrifício. A partir de sua experiência de vida pessoal, eles traduzem suas feridas em ações performativas para buscar autenticidade e falar sobre preocupações existenciais pertencentes à humanidade, ao indivíduo e à sociedade.

\section{RESUMEN}

Este texto está formado de una serie de conversaciones detalladas con Andrea Pagnes, del dúo de performance arte VestAndPage (artista italiano Andrea Pagnes y la artista alemana Verena Stenke) sobre las cuestiones de dolor, sufrimiento y rituales de sangre en sus performances. EI VestAndPage realiza actos físicos extremos en situaciones constrictivas, no para santificar el dolor, y sícomo posibilidades de un encuentro poético con el sufrimiento como fuente de creatividad, para de esta forma, libertar la estética de la justificación del sacrificio. A partir de su experiencia de vida personal, ellos traducen sus heridas en acciones performativas para buscar autenticidad y hablar sobre preocupaciones existenciales pertenecientes a la humanidad, al individuo y a la sociedad.

\section{KEYWORDS:}

Body. Pain. Suffering. Blood. Performance art.
Palavras-chave: Corpo. Dor. Sofrimento. Sangue. Arte da performance.

\section{Palabras clave:} Cuerpo. Dolor. Sufrimiento. Sangre. Arte de performance. 


\section{INTRODUCTION}

\section{Pioneer Performance AND body artists that}

enacted voluntary self-inflicted violent acts, or engaged in extreme physical self-harmful actions, did so to test their physical limits and reach their pain threshold to sublimate pain for personal transformation. Gina Pane, Escalade non-anesthésiée (1971), Chris Burden, Through the Night Softly (1973) and TransFixed (1974) and Marina Abramovic, Rhythm 0 (1974) and Lips of Thomas (1975) are only a few among the most seminal artistic experimentation of this kind. In these performances, artists' pain tolerance seemed almost liturgical, resulting in a quasi-glorification of artist's sacrifice and their capacity for pain resistance and endurance. In some way, they anticipated the concept of 'sacrificial aesthetic', which describes a situation in which "[...] aesthetic forms remain sacrificial, but 'sacrifice' is no longer understood as a necessary feature of social organisation; it is merely a psychological element of the human condition." (PERLEMUTTER, 2000, p. 1) In fact, 'sacrificial aesthetic' claims the “[...] end of the ability of the esthetic to discriminate between the sacrificial and the anti-sacrificial [...] and liberates the esthetic from the ethical end of justifying sacrifice." (GANS, 1999)

However, when analysing these groundbreaking, cutting-edge works more in depth, they were not only attempting to find new forms of the sacred reclaiming the spiritual in a personal way. Beyond the ideas of the artist as a scapegoat and 
ritualistic cruelty, they also aimed to re-imagine the 'social contract,' a "theory, nearly as old as philosophy itself", (FRIEND, 1995) so as to subvert the social agreement that establishes explicit and implicit moral rules, norms and behavioural policies. ${ }^{1}$ The fundamental values of Western culture were deeply challenged, to such an extent that censorship spread over several alternative forms of cultural production and consequently on many levels of society. (PERLEMUTTER, 2000)

This text will illustrate VestAndPage's response to the question of whether the notions of pain, sacrifice and suffering are tackled as obligatory passages to inquire performance art as an urgency to explore the physical limits, the psychological characteristics and the spiritual qualities of the body.

Exploring what as human beings we still have to offer, and the ephemeral matter of human existence, which is increasingly characterised by social exclusion and global atrocities, in their works they re-imagine the 'social contract' in terms of 'poetics of relations.' They examine notions of temporalities, memory strata, interpersonal communication, vulnerability and failure of the individual and the collective within social and environmental spheres to propose alternatives to moral principles, social obligations, political contrivances and religious dogmas.

VestAndPage believe that pain and suffering define the boundaries and limits of the human being. They are nestled in the feelings of love and compassion. When the concept of sacrifice is associated with them, they both reveal the flesh, but this is only one aspect of their artistic research. In their performances, performing pain through pain and in constrictive situations that may appear raw and sacrificial is in order to create metaphors that speak of conditions of loss and precariousness that the individual suffers in the capitalist society. In fact, in the capitalist society, the issue of expenditure is inseparable from that of loss. Being sacrifice the highest form of expenditure, it involves a consecration of pure loss and also has a transgressive function, representing a collective crime that bound the community together and helped regulate its internal violence, so: "One could, therefore, understand nothing about sacrifice if one looked at it in terms of individual victim." (RICHARDSON, 1998, p. 61)

1 In Friend's definition "social contract theory is the view that a person's moral and political obligations are dependent upon a contract or agreement among them to form the society in which they live. Thomas Hobbes, John Locke and Jean-Jacques Rousseau are the bestknown proponents of this enormously influential theory, which has been one of the most dominant theories within moral and political theory throughout the history of the modern West." Notwithstanding, "contemporary feminists and race-conscious philosophers have argued that social contract theory is at least an incomplete picture of our moral and political lives, and may in fact camouflage some of the ways in which the contract is itself parasitical upon the subjugations of classes of persons," this way legitimising political authority and coercion over people. 
VestAndPage attempt to give an artistic form of expression through live images

to deeply rooted sentiments that make one vulnerable and thus inadequate to this society. To do so, in their performances they often seek to inhabit disorienting liminal spaces, as in Thou Twin of Slumber: Chrysalis (2013) with Stenke boxed for about an hour in a plexiglas case that limited her any movement and forced her to slow her breath for the lack of air (Figure 1). To demonstrate and criticise how division and separation are applied socially and politically as mechanisms, in DYAD I: Black and White (2014) Stenke constrained her movements by applying bags of water and smoke on her body, which she left it vulnerable, suspended in mid-air with no possibility of further liberating action in the surrounding space (Figure 2).

\footnotetext{
Figure 1 - VestAndPage, Thou Twin of Slumber:

Chrysalis (2013). Grace Exhibition Space, New York, US

Photograph by David Crespo.
} 
From the live images that VestAndPage create and enact with their bodies, a

cathartic aspect emerges. Through George Bataille's eyes, they assume sacrifice as that which brings " [...] life and death into harmony and cuts through [...] to the unknown". (BATAILLE, 1986, p. 91)

Their actions are not about individual victimisation or to merely enact a mystical momentum. They are breathing metaphors to voice broader issues that affect contemporary capitalistic, consumerist societies, i.e. those of seclusion, exclusion, reclusion, accumulation of capital at the expense of others, legalized state injustices, illegal financial crimes, and the consequent damaging lack, deprivation or denial of material benefits considered to be basic necessities in a society.

For example, in the durational performance experiment about unfreedom and the struggle for freedom Without Tuition or Restraint (2011), Pagnes performed jailed inside a dog crate in the gallery space for five days and four nights consecutively (Figure 3 and 4). Stenke was free to perform around the cage (one durational

FIGURE 2 VestANDPAGE, DYAD I: BLACK AND WHITE (2014) HUB14, TORONTO, CA Photograph by Henry Chan. action until physical exhaustion each day and night). 
Figure 4 - VestAndPage, Without Tuition or Restraint (2011).

The Newlyn \& Exchange Gallery, Penzance, UK

Photograph by Simone Donati for Isole Comprese Teatro

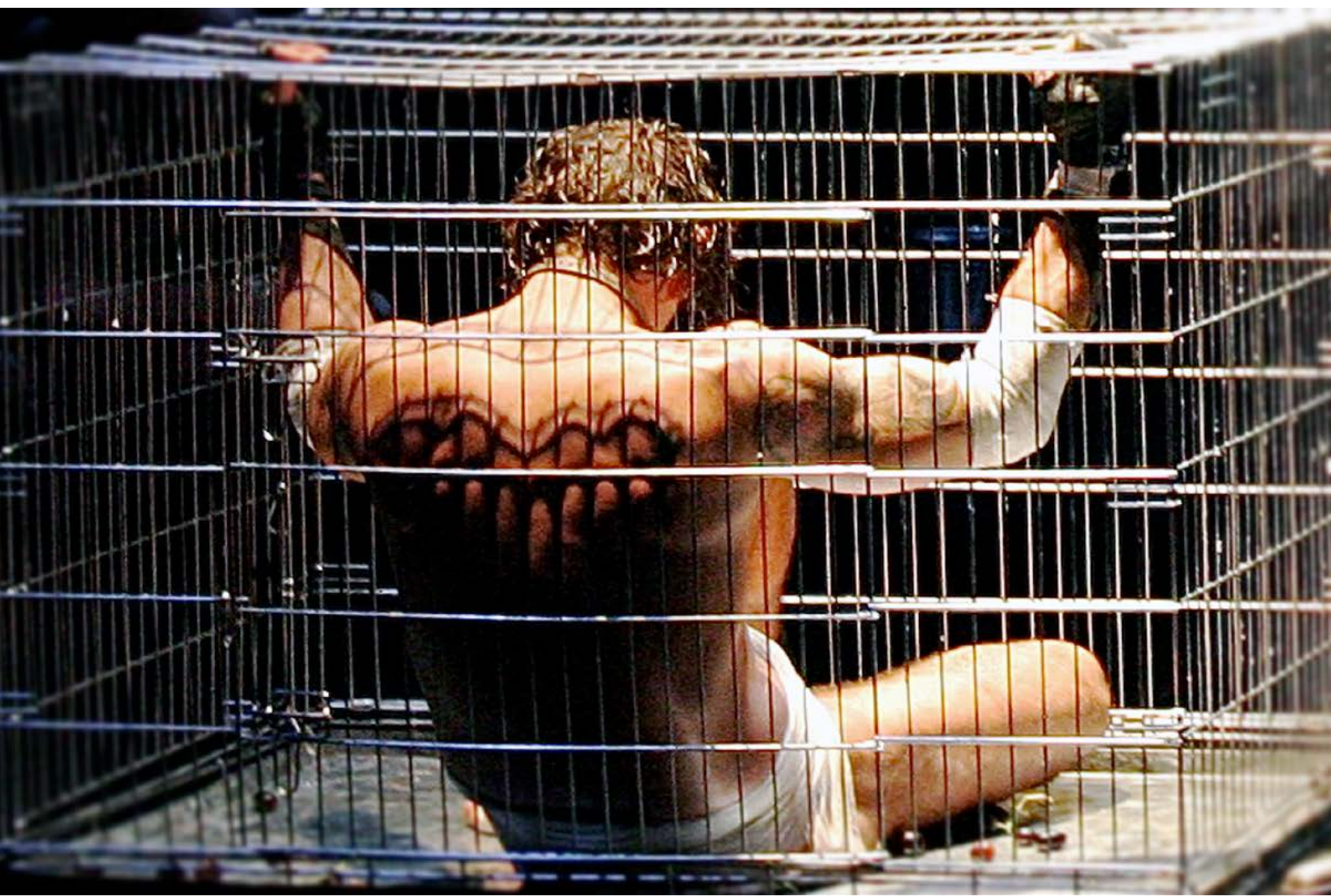


Notwithstanding, with the time passing by, the audience who came and went

back to see the performance, understood that also Stenke had no way out but performing with no apparent cause or solution, as she looked like imprisoned as well in that same enclosed large gallery space: "What is liberty without wisdom and without virtue? It is the greatest of all possible evils; for its folly, vice, and madness, without tuition or restraint." (BURKE, 1987, p. 216)

By going into the flesh of their bodies, VestAndPage try and reach the political, social and fragile bodies of others. Their performances arise philosophical complication, but their acts are never shock-tactics to impress. Instead, they aim to create poetic live images that provoke reflection in the viewer. In their words, they believe that 'to sacrifice' is also a way to become more consistent, compatible and no longer opposed to the others. They see it as an opportunity to find a place that allows them to settle their inner conflicts with the apparent external differences, re-establishing a friendly relation between the Self and its opponents.

With regards to the pain and the suffering of the others, the common tendency is to recognise them mainly from “visible bodily damage or a disease label” (SCARRY, 1985, p. 56), evident stigmas that are clear indicators of pain. However, there are also other types of pain that live and meander invisible within the soul, which most of the times are difficult to perceive and recognise in a person, for example, those that derive from unresolved traumas because of physical and sexual abuses. In DYAD IX: Open \& Closed (2015), VestAndPage performed durational for three days as a Jedermann couple, confronting their inner conflicts reciprocally and suffering through expressions of radical tenderness and unconditional love as an antidote to their suffering (Figure 5). In the participatory performance AEGIS III: Courage (2016), the performance duo denounced the widespread domestic violence perpetrated against women and children. Before ending the performance, they invited members of the audience to speak out loud on a microphone connected to a voice looper the abuses that they suffered. A collective voice rose up and turned into a musical chorus. Pains of the same derivation were shared, mitigated in a final sincere embrace (Figure 6). 
Figure 5 - VestandPage, dyad ix: Open \& Closed (2015). Solyanka State Gallery, Moscow, RU Video still by VestAndPage.

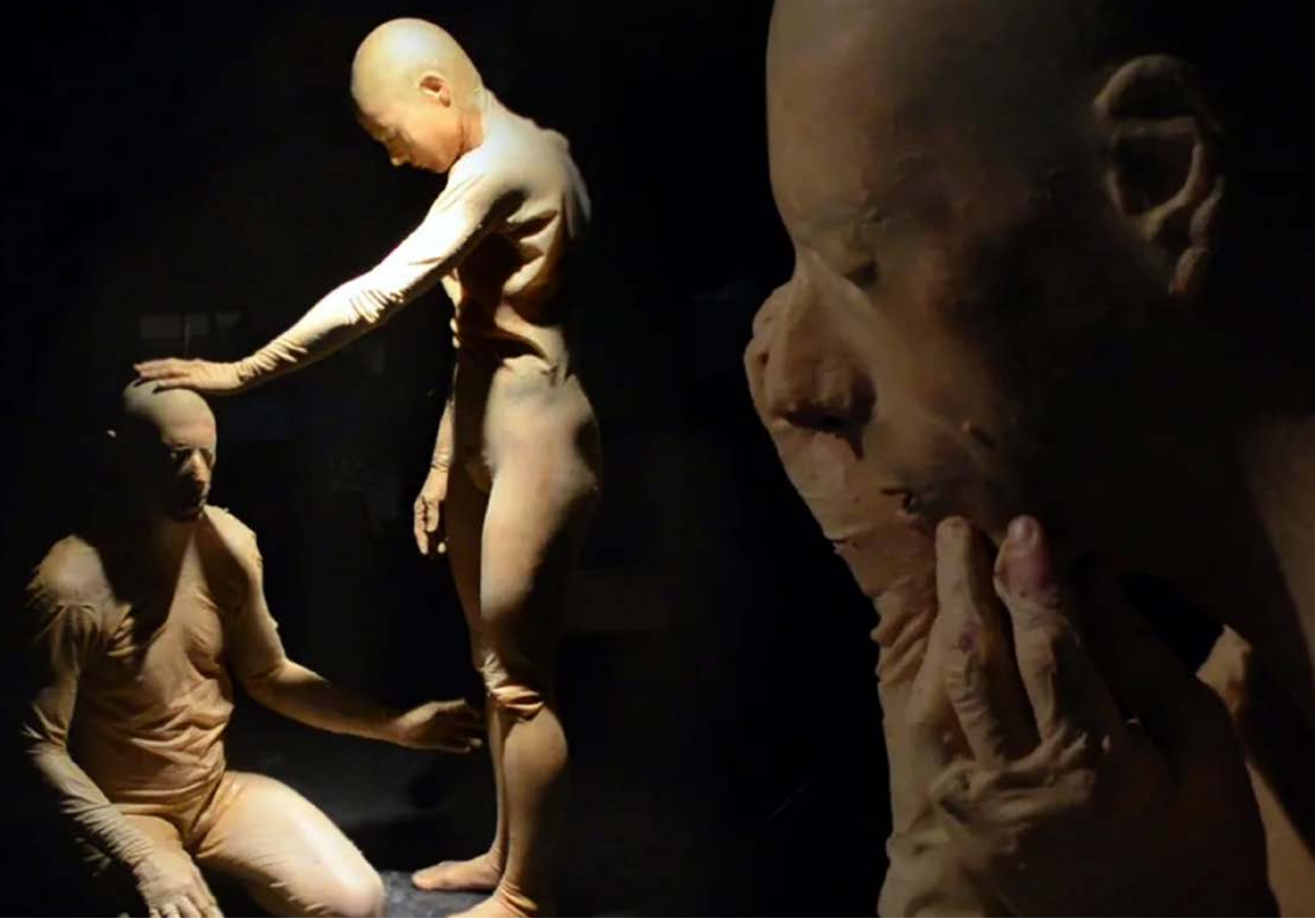


To improve perceptual ability, VestAndPage exercise a constant awareness towards what is not visible to the eyes by following specific training that they have developed from Social Theatre, Sufi Theatre, Physical Theatre practices and Dynamic Breathing techniques. For them, beyond the physical configuration of the bodies, as they appear in reality, there is a universe of invisible, subtle energies that vibrate and resonate. To feel, sense and perceive are faculties they harness to comprehend emphatically and with compassion the invisible pain and suffering of others, to voice through artistic actions that which often cannot be understood.

Indeed, they perform to find a more in-depth intimate dialogue with life: the reality, the being, between themselves and within themselves, not neglecting the aesthetic proposition, which as their primary concern should always be clear. They say:

\section{Each performance should be well pondered and methodologically} organised to become a proper work of art. There is no therapeutic intention in our works: we dig into the bottom of our hearts, and what we find down there we let it emerge as the 'materia prima' (the raw material) of our performances. We do not aim to exorcise our inner suffering by performing. Rather we surrender to it to transform it into a source of inspiration and endless creativity. If anything, it is art itself that gives us the possibility to deal with our 
with them as 'faithful companions'. For us, it is imperative to speak

and make art from our inner truth to come to terms with our true nature. In other words, the less we struggle with our suffering, the more it will talk to us to eventually set us free. It is an everyday practice aimed not just to resolve and surmount suffering, but rather to learn how to consider it as something positive and powerful for the growth of being. (VESTANDPAGE, 2018b)

VestAndPage discuss how some performers operate acts of self-mutilation while performing to make their interior wounds visible exteriorly. By acting on his/her body this way, the self-inflicted stigma becomes a vehicle and a possibility to express the performer's suffering to others, and a way to shape, affirm, recall and confirm his/her own identity. Performance artists who have a higher physical pain threshold than others, do so also to push their physical limits and test their resistance to physical pain itself. Others do so as a political act. Piercing, mutilation, scarification, branding, and sub-dermal implants on the body are also a way to express particular political statements.

In respect to these body art practices, VestAndPage say:

One may object that there is self-indulgence, self-referentiality by doing so or a certain veiled self-victimhood of the performer alongside his/her need of self-proclaiming as a neo-martyr, or a neo-shaman. Often, while experiencing these works, one may think of the shock tactics as a way to impress the viewer. It is undeniable that the tortured flesh and poured blood, in general, produces images that can cause a disturbance in those who are not used to seeing those images live. However, to criticise these kinds of practices in such a way is a waste of time where 'binary' thought veils the viewer of a deeper understanding that may be accessible to him/her otherwise. For instance, ORLAN's Carnal Art is not a longing for pain. She is interested in the process of the surgical operation as a performative intervention, where the modified body becomes the subject of public debate. For her narcissism is a quality of being, an exquisite artistic quality if 
inhabited well and if the subject is comfortable with it. Stelarc's

suspensions, actions that have little to do with the questions of suffering and pain, they are not even made exclusively to demonstrate how he can push his physical limits. Rather they are experiments with a specific scientific purpose. They investigate the issues of the obsolescence of the human body and the impact of the force of gravity. Stelarc did several of his suspensions in the absence of a proper audience, many of them that lasted just for a few minutes. With no qualm, he once told us that there is also a kind of pleasure when he does a suspension with his skin pierced by shark hooks, not just physical pleasure but also an aesthetic one, intellectual, subtler and refined. However, in the BDSM area body-artists practice self-mutilation and suspension mainly to provoke a particular excitement (if not morbidity) in who's watching as well as in themselves, and yet, it's also undeniable that when these performances are well conceived and prepared, they often present interesting aspects of a fresh ritualization of the human body itself. (VESTANDPAGE, 2018a)

VestAndPage's approach to the use of extreme body art elements is slightly different. In their performances, upside down rope suspensions, scalpelling, self-cutting and blood extraction are elements that concur with the overall creation of poetic live-images. When those images portray inner pain or suffering, they do so in poetic terms. Extreme body art elements belong to those live poetic images and concur to form those images. They are like their tools to investigate their deepest most private concerns.

In their words, what is of importance to them is the performativity of the poetic living-image itself grasped in its ephemerality and immediacy; its outcomes, aftermaths, relics, and residuals, and how it activates the memory, both in us and who's present, because in a performance poetic-live images meaningfully address "concrete realities of human existence as if to say that they are always sincere. (PAGNES, 2012, p. 51) 
The element of ritual appears in a wide variety of performance pieces since the earliest forms of performance art. VestAndPage's choice of ritualising the use of blood along with their iconic hazardous materials with which they perform has been long meditated to facilitate presence and intuitive responsiveness. Their repertoire of materials consists of glass and mirrors shards, as in AEGIS VI: Home (2017) (Figure 7); knives, blades, nails, barbed wire, ropes, or natural latex fabrics and strings like in HOME V: Mother (2018) (Figure 8); slippery substances, fluids, blocks of ice on which they dance or lay naked; fire drops and flames falling directly on their flesh or held in their hands until they can, like in The Smile at the Top of the Ladder (2012) (Figure 9). In their live performances, VestAndPage use these materials to set up situations that are constrictive to solicit their sensorial responsiveness and operate with full awareness in the here and now.

Figure 7 - VestAndPage, AEGIS VI: HOME (2017).

State Museum of

Contemporary Art,

THESSALONIKI, GR

Photograph by DAZ DISLEY.

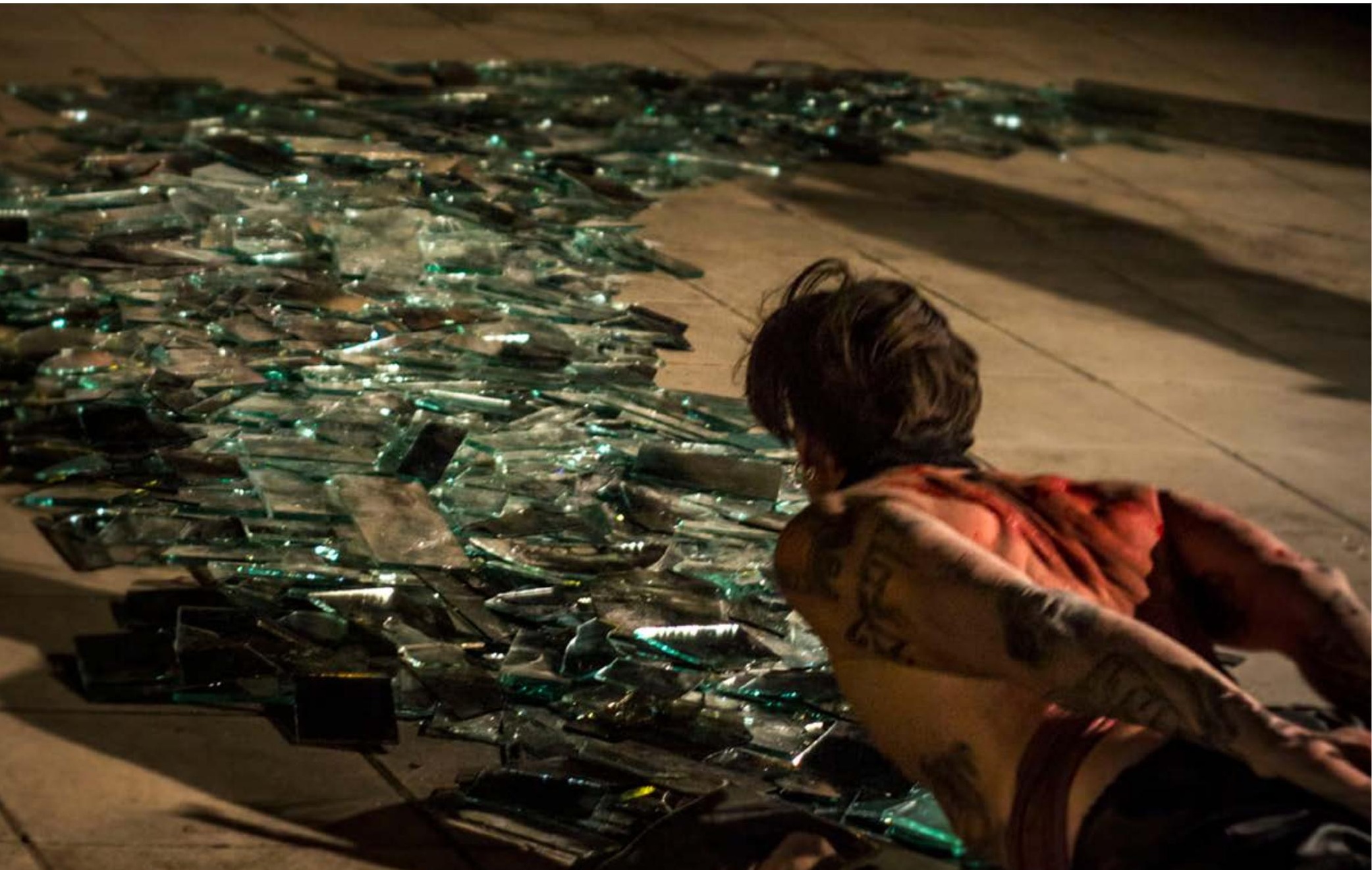


Figure 8 - VestAndPage, HOME V: MOTHER (2018).

National Gallery of Arts, SOPOT, PL

Photograph by Franko B.

Figure 9 - VestAndPage,

THE SMILE AT THE TOP OF THE LADDER (2012). FONDERIA 900,

ROME, IT

Video still by Human INSTALLATIONS. 
They perform this way because it leads directly to intuitive decisions that must be taken in the immediacy. In his theory of sacrifice, Girard (1972, p. 37) argues that blood rituals are nothing more than regular practice to exercise beneficial violence and validate the notion of sacrifice:

the physical metamorphoses of spilt blood can stand for the double nature of violence, harmful and beneficial [...] Blood serves to illustrate the point that the same substance can stain or cleanse, contaminate or purify, drive men to fury and murder or appease their anger and restore them to life.

A ritual implies a cathartic process, but VestAndPage do not enact the sacrifice to become sacrificial characters themselves. In their performances, the use of blood (and its ritualisation) has nothing to do with Girard's concept of beneficial violence. As it is distant from the concept of purification of Catholic derivation, which calls us to: “cleanse ourselves from every defilement of body and spirit," (CORINTHIANS, $7: 1,2013$, p. 757), which recalls another religious concept, mortification, (form the Ecclesiastical Latin 'mortificare': to put to death), that in a large variety of religious traditions occurs in the context of initiation rituals. (SABBATUCCI, 1987, p. 113114) The catharsis, for them, is mainly “[...] the process of emotional discharge, relieving the emotional tension" (SCHEFF, 1979, p. 45) that the performance sets up for them and audience/participant alike. In their works, there is more romance than violence; a feeling of mystery associated with love, dreaming and remoteness from everyday life. They use their blood for the pure matter that it is: an essential body fluid, vital lymph par excellence, a vivid organic red 'ink' that rushes inside the veins, crimson drops of genetic and hereditary information.

For VestAndPage, in their performances blood symbolic and metaphorical value is likened to the poor painter of an ancient Zen story who had no money to buy colours but one day by accidentally cutting his hand, he discovered that he could paint a beautiful painting just with his blood. Pagnes says: 
it to stay in the present and move towards our future. To say it 2019.1 poetically, to let the blood spill gently out of our body is like to remember dancing between illusion, mythmaking and forgetfulness, a concept that we have grounded with the performance The Smile at the Top of the Ladder (2012). Inspired by Henry Miller's book The Smile at the Foot of the Ladder (1959), Heinrich Böll's novel Ansichten eines Clowns (1963) and Bruce Nauman's Clown Torture video installations (1984-87), the second part of this performance revolves around an intermittent frantic dialogue on the absurdity of life to which one cannot escape. When I went into telling about the side effects of memory loss and consequent existential disorder, I began slowly to engrave onto my chest the Latin word ire with a switchblade hidden in my hand [Figure 10]. The English translation of ire is 'anger. In the Italian language, it has a double meaning: it can mean ira (Eng. 'rages') or andare (Eng. 'to go' and figuratively ‘to let go'). By that, I would mean that in our work, we also pay a great deal of attention to the semantic value and ambiguous changes relating to or arising from the different meanings of words or other symbols whose meaning is forgotten or misinterpreted. Having studied art, literature and aesthetics with specific reference to the Magnus Opus and the Labor Alchymicum, the magic-hermetic tradition and that of the ancient alchemists, such as Roger Bacon, Chaucer, Paracelsus, Giordano Bruno, Pico Della Mirandola, Cornelius Agrippa and moreover Avicenna, who is considered the father of early modern medicine and theorised subjectivity, has informed our artistic path. Avicenna, in his De Anima, took into account the internal awareness of the objects other than the subject of awareness and the subject awareness of itself. 'Ps. Avicenna openly gives preference to blood: blood is considered the soul of man, because it is by way of his blood that man lives'. (MOUREAU, 2013, p. 289) The sentence attributed to Avicenna translated into Latin of a lost Arabic original and transcribed by Mino Celsi: 'Et anima est sanguis et sanguis est anima, et tota anima sanguis et totus sanguis anima, et qui aliter credit non tenet naturam philosophi,' ([pseudo-] 
AVICENNA, 1572, p. 275) in some way also recalls the Jews' belief

that the soul resides in the blood. In fact, Avicenna's statement reminds of the Leviticus (the third book of the Torah and the Old Testament): "For the life of the flesh is in the blood, and I have given it for you on the altar to make atonement for your souls, for it is the blood that makes atonement by the life.' (LEVITICUS $17: 11,2011)$ In short, to assume that the life force of the flesh is in the blood and its innermost essence is the soul, it is an interesting position that fascinates our imagination. To what extent the ancient alchemical thought can be related to contemporary creative thinking? (VESTANDPAGE, 2018a)

Of course, VestAndPage do not use their blood to explore elixir system and ferment system notions like the ancient alchemists, who distilled blood as liquor in alembics and ampoules to reach the very essence of the soul. Also stepping back from classic Body art, if anything they use alchemical, medical, and surgical devices to extract their blood from their bodies and ritualise it into a stream of consciousness writing, poetic words, texts, diagrams and drawings, which pertain to the specific theme of a particular performance. For them, blood is an element to produce real poetry while they perform.

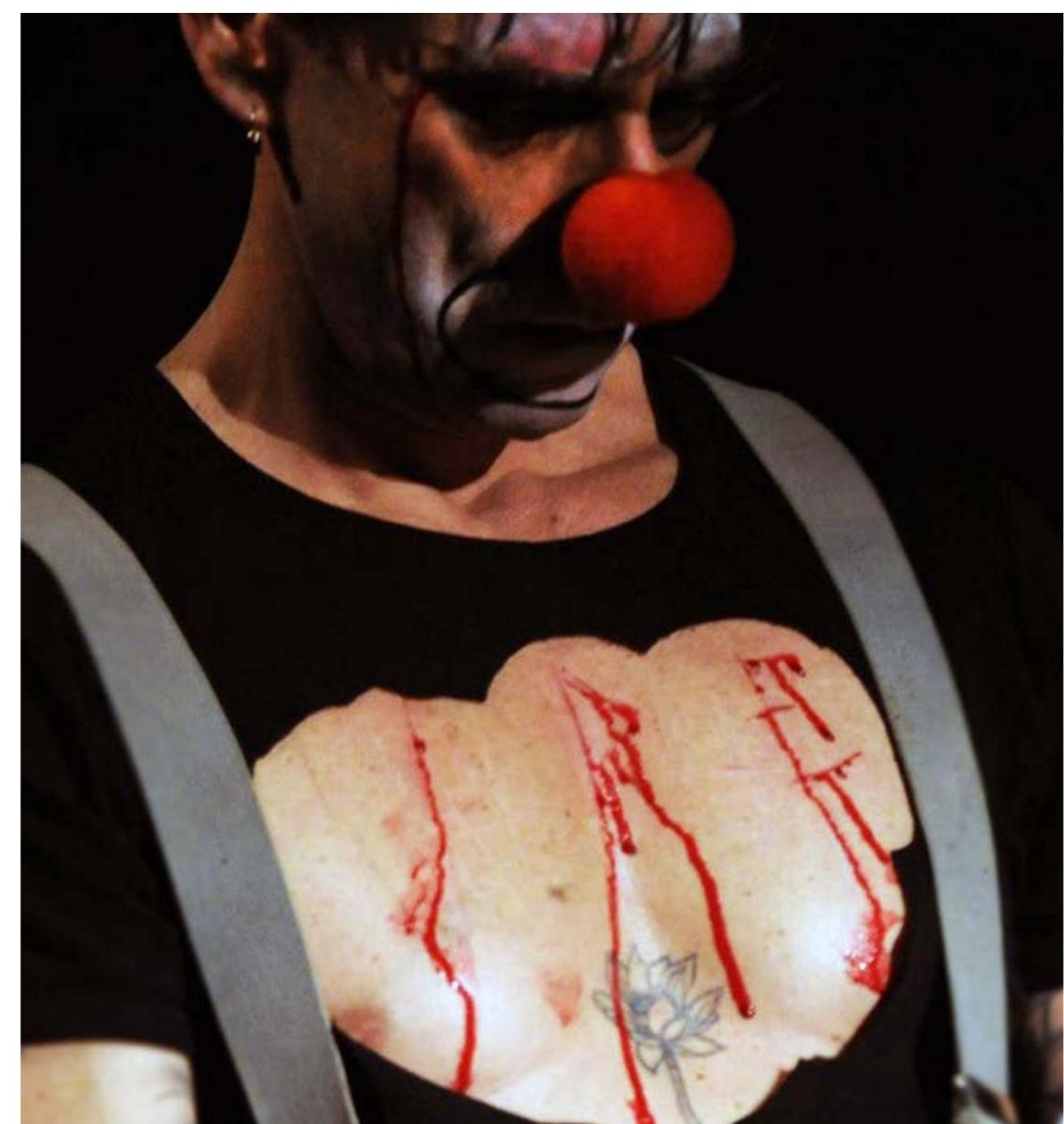


They assert to be inspired by a core passage of 'Coleridge the Traitor' by Antonin Artaud, the letter he wrote to Henry Parisot on November 17, 1946:

\begin{abstract}
I say real poetry, poetic poetry, etic: charming hiccup with a bloody backdrop, the backdrop forced into the poematic, into the cracks of a bleeding haemorrhaging reality. For afterwards, let's say after the 'poematic' will come back the time of blood. Since ema in Greek means blood, so po-ema should mean: afterwards: the blood, the blood afterwards. First let's make poems, with blood. (HIRSCHMAN, 1965, p. 131)
\end{abstract}

This discourse is valid for VestAndPage, it is not necessarily valid for everyone, nor do they aspire that it should be so. Eventually, they are interested in exploring blood as an organic fluid material in its twofold metaphorical value: carrier of suffering but, mainly, as an expression of life.

\footnotetext{
All works of art carry different meanings and are open to a variety of interpretations. As artists, we constantly navigate across a sea of metaphors, symbols and analogies, which are more or less real than reality itself. When we perform it is like we have docked in a harbour, we need to establish where we are exactly, re-affirm ourselves and from there start again. We do not represent 'this or that'; rather we present our actual state of being, which is real and, hopefully, poetic, and nothing more. (VESTANDPAGE, 2017)
}

VestAndPage's performative actions are not intended to be a projection of reality. They tell of the dream of life that they have and the hard, sometimes painful conflicts that they encounter to make this dream come true. In art, the use of essential metaphors formalises the desire to deal with a condition or a state, i.e. of suffering, is the possibility of solutions and restraints. Over time, they have learnt that the unwanted corners of their being must not be concealed. For them to perform from their truth, it is essential to zoom in on the aspects that have reached their inner being through performing itself. They say that 
to perform in this way allows us to put our mental contrivances

into motion and for our emotional intelligence to express itself with greater freedom and intensity: to reach the audience more powerfully. When personal pain and suffering are felt too much as heavy burdens, a weight that overwhelms, they can make us incapable of distinguishing between reality and illusion. Indeed, pain is difficult to overcome, for everyone, but in art, it can serve as precious material to ask questions on issues and concerns demanding urgent responses, the autonomy of decisions and a clear sense of vision. The ritualistic aspects are part of a greater journey that we undertake not just while performing, but also when we think and reflect on performance matters. If through repetition, will or desire we go through pain and suffering, in our performances, there is almost no concession to the concept of sacrifice. Our ritualisation of blood is to extract from our bodies a sheer substance to deliver sheer poetry. It is as if we seem to recognise in blood the capacity to achieve an impossible poetic utopia, and exercise freely our right to exist. In a performance, catharsis and art-making processes often follow parallel paths; one explains the other and vice versa. Also, it offers us the possibility to re-discuss our role continuously as artists, how we relate to the others and renovate ourselves, keeping our human and artistic integrity intact. (VESTANDPAGE, 2018b)

Of course, the use of blood can provoke immediate and involuntary reactions in who's watching. It can colonise other (private) spaces, and because of this, it can lead the way to other possibilities unknown before. Whether lived emotions and suffering disappear through a ritualisation of the blood in performance, VestAndPage cannot tell. They say it would be very pretentious to say so. What they can say is that the ritualisation of blood in their performances serves ideally to reach a place where they can recognise that time has passed and has delivered something precious to the present and that precious things are now there to be revealed. It is a place where the consciousness feels refreshed because they have cast off stagnating certainties and put into play their critical awareness. 
Nonetheless, also there is something more personal and profound: an act of reconciliation with their bloodlines, trying to settle and resolve something that they could not before, which, in the affective sphere, allows them to accept the changes that have occurred in their life-paths and embody them as experience. For German Verena Stenke, it is the post II World War trauma that suffered her family and still affects the Deutsche Seele (German soul) involving a large part of the younger generations, for severe stress can be hereditary as analysed by Sereny Gitta (2000), an Austrian-British biographer, historian, and investigative journalist. For Venetian born Andrea Pagnes, who soon lost his father in unjust, obscure circumstances, not to compromise his political ideals, it is the difficult task of shouldering the burden of redemption and the impossibility of acknowledging the real facts.

\section{VESTANDPAGE'S PSYCHOLOGICAL PERSPECTIVE AND PERSONAL EXPERIENCE}

Psychiatrists' reports show that among adolescents there is an increasing diffusion of self-cutting practices acted in moments of great anguish, emotional suffering and a consequent dying passion for living. Losses and unsolved traumas are often associated with these practices that reflect a psychological pain of the subject. The concepts of suffering, psychache, emotional pain and psychic pain could contribute to a definition of psychological pain that

may best be defined as a lasting, unsustainable, and unpleasant feeling resulting from the negative appraisal of an inability or deficiency of the self. This negative self-appraisal is typically brought on by the loss of someone or something, or failure to achieve something intimately linked to core psychological needs. 
In the fields of social psychology and personality psychology, the dying passion for living caused by inner suffering and psychological pain indicates that the subject is in desperate need of something which he/she cannot find anywhere, and nobody can give to him/her. The subject lives in a state of emotional agony, unable to fulfil his/her need for love, autonomy, self-achievement, or the need to avoid harm, shame, embarrassment, the threat to social connection, bereavement, mourning, grief, sorrow and an inescapable feeling of continuous, pervasive piercing sadness (MACDONALD, 2009) Technical terms of this psychological condition include algopsychalia, a mental distress

also known as a psychalgia, phrenalgia, mind pain, soul pain, psychic pain, and psychogenic pain. The term algopsychalia comes from the Greek words algos (pain) and psuchè (life breath, spirit, soul, mind). It translates loosely as 'mental pain.' It refers to a bodily sensation of pain that is recognised by the individual as being mental rather than physical in origin. Algopsychalia tends to be classified as a psychogenic hallucination or as a variant of sensory conversion. Conceptually, it is related to hallucinated pain. However, it should not be confused with pain syndromes such as allodynia, dysaesthesia, paraesthesia, and hyperpathia. (BLOOM, 2010, p. 13)

By definition, psychological pain or "psychic pain is an intolerable pain caused by intense psychological suffering rather than physical dysfunction." (VANDENBOS, 2007) It can be also defined as emotional in origin. "Psychological pain is not the same as bodily or physical pain. It is how you feel as a person; how you feel in your mind. It refers to how much you hurt as a human being. It is mental suffering; mental torment. It is called psychache." (SHNEIDMAN, 1996, p. 173) It can derive from prolonged states of anxiety, anguish and loneliness, obsessive fears, conscious or unconscious sense of guilt, hallucinations, suffered humiliation, phobias, paranoia, lasting sadness, unbearable shame and unsustainable shyness. It can be to such a degree that it becomes pathological, excessive and somatic, affecting the subject's existence negatively in all senses, causing i.e. depression and also schizophrenia. "Psychic pain, which is an unavoidable part of existence, derives from unconscious layers of the personality and is rooted in early, preverbal experiences, on the border between the somatic and the psychic." (WILLIE, 2011, p. 23) 
Psychic pain / soul pain is a predominant topic in VestAndPage's artistic research: they discuss how these practices are also in use among drug addicts. Andrea Pagnes himself comes from a long rehab, due to drug abuse in his youth, which brought him consequent psychological stress disorder, depression and lived condition of discomfort. During his rehabilitation program, to understand and come to terms with the causes that led him to recur to heavy Class A drugs as a form of elusive spiritual nourishment, Pagnes began to study and practice therapeutically transitional analysis, as developed by Eric Berne, which can be considered a relational evolution of Freudian psychoanalysis. The empirical and phenomenological bases, together with an epistemological apparatus supported by philosophical pragmatism, make transitional analysis not only a theory of personality but also a theory of relational communication and behaviour. It theorises the ego as formed by three structures represented as a single personality and coherent organisations of thought, feeling, and behaviour, each with its functions: parent (exteropsychic/identificatory); adult (neopsychic/data-processing); child (archaeopsychic/regressive). (BERNE, 1961)

While digging at the roots of his malaise, Pagnes found many of the answers he was looking for in reading Jacques Lacan, particularly his Psychoanalytic Discourse (1972), there where is unfolded the Discourse of the Capitalist, and in the practice of Social Theatre. Performing alongside actors-non-actors belonging to so-called 'social disadvantaged categories,' led him to understand how many effective performative actions are often born precisely from the stigmas that connote a person. From to 2004 to 2009, Pagnes, and from 2006 also Stenke, operated in Social Theatre aside performers indelibly marked on their bodies by congenital or contracted diseases, or signed by challenging life experiences. Being Social Theatre a theatre of research, multifaceted and experimental that draws from reality, its language and content have a clear socio-political derivation and orientation, where real-life experiences of the performers are often the primary source for the final public performance. Sharing the stage with actors-non-actors (inmates, former drug addicts, sex workers, refugees, psychic and Down syndrome patients) or blind, deaf and differently-abled people, brought VestAndPage to look at performing art practices and art in general from a broader perspective and in terms of social responsibility. Pagnes discusses: 
To inject drugs, elsewhere named 'the practice of the hole', is

often accompanied by practices of physical self-harming of different genres. If at the beginning of the addiction those marks are hidden, in many subjects they gradually become they become identifying signs to be exhibited without hesitation, almost to 'glorify.' Often those who inject drugs do it primarily as an act of rejection to the society in which they live. Although it is a harmful, self-destructive, narcissistic act, paradoxically it is somehow also an act of rebellion that has strong political connotations, even if not everyone who does so realises it. In other words, the subject that asserts his/her rebellion through self-invasive practices declares to be in revolt against something that he/she does not want or cannot accept. This behaviour underlies the attempt of the subject of re-appropriating his/her lost identity and reaffirms it in front of all that he/she refuses and is against - family, society, norms, rules, and so on. To forge an identity borrowed from a practice that leaves its mark is not, however, 'privilege' of just drug addicts or teenagers admitted to a psychiatric hospital. Piercing and tattooing, but also cutting and branding, which are far more invasive and violent scarification practices, have now become part of youth aesthetic practices, which in the trivialization of their inclusion in fashion phenomena, conceal their profound and disturbing value of discomfort and subjective malaise. As Italian curator and Lacanian scholar Patrizio Peterlini has accurately analysed (2013), such practices, which underpin a 'fetishist attachment to some objects - the so-called substances of addiction - based on unconscious partial drive functions' (SVOLOS, 2011, p. 82), can be put in close relationship with the Discourse of the Capitalist by Jacques Lacan and unfold as a consequence of this discourse. In the Discourse of the Capitalist, Lacan demonstrates how capitalism is a false democracy that promises the unlimited circulation of objects of consumption and the right that each of us has to their enjoyment. On the contrary, it is a vicious circle that continually creates pseudo-shortcomings that can fuel the consumption circuit. Everything must be consumed incessantly, 
to satisfy a globalising expansion in the illusion that in this infinite consummation the 'lack of being' that constitutes our existence can be magically resolved. (VESTANDPAGE, 2018a)

VestAndPage (2018a) believe that:

the maniacal offer of the object to be consumed made available on the market through the spectacular metamorphosis of its fake aspects, creates a fictitious reality in which many do not recognise themselves anymore. The consumerist system purposefully creates a continuous sense of materialistic lack and non-fulfilment. The consequence is that the individual constantly faces an existential emptiness. For the drug addict, the object-substance (the drug) stops any possibility of lacking but obliges the addict to dig into the reality of his body, a 'hole' that has the function of allowing the subject to confirm his/her identity through a toxic signifier. It is a non-solution in the end because paradoxically it serves the subject to affirm him/herself by obliging him/her to fight cruelly with his/her own body, for this is the only way that he/she can meet the Other.

For VestAndPage the drug addict who shows his/her identification with a reality that he/she does not accept is, in a way, also a martyr dominated by passion, as being impassioned is also suffering. In this sense, the drug addict is the martyr of the Discourse of the Capitalist, testifying to its strength, its dominance and at the same time scarifies him/herself in a desperate attempt to highlight its deadly limits. The addict finds in these harmful practices the possibility of naming his/ herself, even if in the demonstrative form of "I am the one who does this."

VestAndPage understand that the dominant imperative of contemporary society is: consume it / enjoy it. Both in the private and public sphere, this entails not only the dismissal of the judgment of the other and the sense of guilt but also the abolition of the gaze of the other that catches us in our enjoyment. Ostentation, in this sense, is an act of subversion of the moral canons. Shame differs from the sense of guilt in its relationship to the other. In the sense of guilt, the relationship 
is with the other who judges. In shame, the relationship is not with another who

judges but with another who sees (what the other sees and at the same time what one gives to see). Jean-Paul Sartre (1956) refers to shame as that which is closely related to the enjoyment and degradation, which affects the subject in being caught in his enjoyment.

However, we are currently living in an era in which the gaze of the other, which causes shame, has dissolved. Today's trend towards the spectacularization of a reality made by TV, the media and the Internet, easily demonstrate this stance. For example, the reality shows are proof that our eyes, far from creating shame, are only looking for enjoyment the same way. The disappearance of shame indicates that the subject ceases to be represented by a signifier that is worth as a reference. Additionally, it involves the desperate need of the subject wanting a new, precarious form of representation borrowed from the imaginary components linked to his/her enjoyment that serve to identify him/herself.

Lacan, in his seminar on Anxiety (1962-1963), discussed how self-injurious practices, if on one side they reinforce the image of the subject, on the other side they also present themselves as an ultimate appeal to the other. An "acting out" (the actuation of mechanisms of defence and self-control, mostly self-destructive) that the subject operates on him/herself to enter into contact and communicate with the other. The term "acting out" is the translation of the German word Agieren (literally “to act”) used by Freud (1955, p. 196) to indicate contrasting operations of repetition and recollection to bring the past into the present: “The patient does not remember anything of what he has forgotten and repressed, but acts it out. He reproduces it not as a memory, but as an action; he repeats it, without, of course, knowing that he is repeating it."

Also for the French psychoanalyst "acting out" results from a failure to bring the past into the present. However, it is not just a mere act of recollection (to consciousness) as in Freud, because it involves the intersubjective dimension of recollection itself. It is an act - extreme and impossible — of communicating something to the other who refuses to listen. Therefore, from the Lacanian perspective, "acting out" is a symptom, and even though the symptom shows itself as something else, the proof is that it must be interpreted. The staging (mise-en-scene) is the 
most obvious aspect, both in the manner of carrying out the self-destructive act and in the subsequent lamentations focused on the existential desperation that dominates the subject that no one understands. For example, in behavioural and substance addiction, "acting out" offers to the addict a momentum of emotional relief, fleeting pleasure, even spiritual fulfilment. In the illusion of being in control of his/her life and the reality (NAKKEN, 1996), the addict takes drugs as a right medicine, universal cure, sovereign remedy, wonder elixir, magic formula and ultimate solution for all difficulties, eventually a panacea to pursue happiness. The syringe becomes the perfect instrument to perform the act. The holes on his/her flesh are the constellation that maps his/her desperate, precarious resistance to confirm him/herself to the other and the world.

Lacan (2014) indicates that the implications combine the need of showing or demonstrating and that of desiring: to isolate a desire whose essence is to show itself as something else, and yet just by showing itself as something else, to designate and affirm itself as a truth, even if that truth does not belong to the nature of desire. As earlier mentioned, these extreme gestures can sometimes cause repulsion in those who witness them, forcing the other to refuse and dismiss the subject that enacts self-injury. While admitting that it is indeed not easy to remain lucid and rational in the blood that gushes, it is important to remember that all the staging is there for us all, so that we can grasp and interpret it.

In some cases, it is not even a question of acting out, but to transform one's present condition or state into another through actions. If in the acting out the subject turns to the other and the gestures that the subject makes take on the dimension of a message, in the passage to the act the subject excludes the other. It does not aim to be understood. (LACAN, 2014) In other words, it is likely that the subject has chosen to depart from the other to venture into a dimension in which he/she cannot represent him/herself anymore. It is here that the practices of manipulation, corruption, experimentation and even violence on one's own body and the consequent ostentation of connected aesthetic pleasure, assume a completely different value.

The whole history of art consists in demonstrating this evidence. It is precisely the history of recent art that provides people with further elements of investigation 
concerning the acts of self-injury. The history of art (in particular the avant-gardes) provides VestAndPage with a series of experiences that have driven the systematic destruction of human body image, canons of beauty, form and balance over the centuries. Renoir, Cézanne, Braque, Picasso, Léger, Picabia, Arp, Tzara and the Dadaists, the Futurists and the Surrealists have radically changed the aesthetic references of their time. After the Second World War, the systematic disintegration of the old canons of beauty becomes even more direct - the human body is no longer represented but acted for real as it happened, for example in Aktion by Gunter Brus (1965), Material Aktion n.30 by Otto Mühl (1966), and later on with Sentimental Action by Gina Pane (1973). These are works that seek and propose discomfort. The unwatchable, the obscene, and the revolting become new aesthetic values that reversed the conventional ones. Art appears to come out of it massacred with the rise of these artistic practices; instead of elevating man from his most brutal tensions, they are exasperated and brought to the foreground exalting their deadly aspects. (PETERLINI, 2013, p. 115) At that time (but also partly today), acerbic art critics like British Brian Sewell saw in these performances only the deliberate spectacularization of a self-destructive violent and even silly masochistic call to pain practices. As we can see in archival footages from the docufilm Burden, a probing portrait of legendary artist Chris Burden, directed by Richard Dewey and Timothy Marrinan (2016). In truth, however, these performances represented a radical turning point in the whole tradition, breaking through from the imaginary and were directly executed in the real world without any mediation of the symbolic. For VestAndPage these performances are also hymns to life, when they looked at them from a Lacanian perspective because through these extreme actions, the artists courageously face the existential weight of living, and because death is something always present, unpredictable, looming and of which nothing else can be known. Death belongs to the realm of faith: “You are right to believe that you will die. It sustains you. If you did not believe it, could you bear the life you have? If we could not totally rely on the certainty that it will end, how could you bear all this?" (LACAN, 1972) Regarding Body art and the implications inherent in self-harming practices, there are two forms of destruction of beauty, which are sometimes present at the same time. The first form aims at the destruction of the Other or at becoming the object for the enjoyment of the Other. (PETERLINI, 2013) The second aims at searching for the object and passes through the destruction of the specular image as an obstacle "precisely 
where there is indicated that it is only from enjoyment, and not along any other paths that there is established the division by which narcissism is distinguished from a relation to the object." (LACAN, 2001, p. 84)

Theoretically, the destruction of contextualised beauty in the search for knowledge is the destruction of a concept, and it was in this direction that many of the avant-gardes had done their best by systematically destroying the previous aesthetic canons. Paradoxically, the path of the avant-gardes has led to the most radical and unfathomable affirmation of a work of art, to the point that the object/work of art shines precisely in the impossibility of being brought back to the pre-established language or system. Here the art object is 'beautiful,' precisely in its denial of the previous aesthetic canons and affirming new ones. The destruction of the canon of beauty is therefore in these art movements, functional to the possibility of affirming a new meaningful relationship with the truth of the object. (PETERLINI, 2006) This tendency inexorably seeks to highlight the absolute irreducibility of the Thing to its representation, because "[...] the Thing is characterised by the fact that it is impossible for us to imagine it." (LACAN, 1997, p. 125)

Lacan's concept of the Thing as an unknowable $x$, beyond symbolisation, has clear affinities with the Kantian 'thing-in-itself.' For Lacan, the fundamental desire, the drive that moves the human being to live and to understand the unknowable is born with the body. However, it is not in the body or of the body, as it happens for Freud, for whom the drive has an irreducibly biological-bodily origin, and for the branch of the psychoanalysis that argues that the origin of the body is before that of the mind. For Lacan, the proper and specific desire of the human being is that of recognition: what is the answer to the question: "who am I?" Therefore, precisely, the origin of human life does not lie in the body and its material needs, but in questioning oneself on one's own identity, which belongs to a consciousness that is already in some way reflective and self-reflective. However, when the destruction of beauty presents itself as the destruction of the body, what artists want to strike is precisely this radical dichotomy. What VestAndPage want to destroy is the possibility of a reference, of the last guarantee, to deny, close and eliminate the irreducibility of the Lacanian Thing to its representation. In practice, it means preserving the Thing as it is, affirming its autonomous reality. Because the Thing is unattainable, the subject is not able to satisfy the object of his/her desire, therefore 
has no way out other than to turn inwardly, relying on the ego and "[...] it typifies an essential libidinal relationship with the body-image." (LACAN, 1953, p. 14)

For VestAndPage, at the precise moment that the mirror is destroyed, the image of the body crushes itself and sets both the self and the body free. In many of their live actions, they performatively translate this concept by actually crashing, dancing, walking and crawling on broken mirrors and glass shards until they bleed, creating images of poetic pain to face those questions. (MEIER, 2013) Referring back to the issue of whether the actions of pain in VestAndPage's art are to control the uncontrollable, they state that to control something implies the ability to manage, influence, or restrict it. To exercise control on something means to exercise power over it. On the contrary, it is more an act of surrender that VestAndPage enact:

The suffering that we carry within ourselves and the pain that we feel are constitutional to our being. Once we have acknowledged what constitutes our being, it is easier to process our suffering and understand from where it comes. Only then can we learn how to breathe with it. To create art through our body, we need to exercise not exactly control, rather an awareness to act fully consciously, using pain and suffering creatively. Even if we cannot be in control of which interior pain we feel, we can still perform in accordance to it. The process of acknowledging pain and suffering is a tireless work of insight, and it is not definite that there will be satisfactory results in the end, but acceptance of the pain at least. Acting upon our bodies in a certain way is to translate this process of acknowledgement by performatively using our bodies as a tool: a sheet upon which to write on it our vulnerabilities, fragilities and failures as transient distressed mortal beings. When a traumatic, painful experience occurs, the body and mind seem not in sync together for some time. This apparent sensation of disconnection is like a gestation period because the body, the mind and the spirit require a certain amount of time to metabolise and resolve the trauma that has happened. Not always can a person resurface quickly and easily from trauma, it can take a 
long time, but one should be willing to give this process all the

time it needs. In the fortunate circumstances that after some time the body, mind and spirit tune back together, it is like a re-birth jewelled by a new awareness, therefore it is like that the being acquires new integrity, even if that experience was among the most dramatic and painful. Our emergence as artists is to give life to actions that transform into poetic images to express the strength of beauty that resides within each of us. We want to give a chance to pain and suffering to open up a space in which we can be honest to and with ourselves because it evokes responses within ourselves; a space with no judgement and of true encounters. (VESTANDPAGE, 2018a)

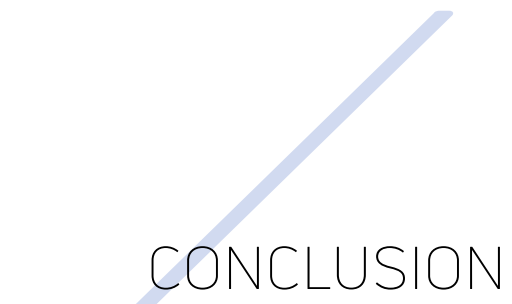

When discussing with VestAndPage their work Panta Rhei V: Matter (2012), they spoke of how some audience members approached them at the end of the performance, describing a sense of inner pain and subsequent release that touched them deeply. What VestAndPage can say is that there were intense moments during this three-day long durational performance, particularly when Pagnes began to invite members of the audience, gently leading them one by one to stand in front of a mirror. Holding their hand, asking to watch the mirror, whispering to each of them to think intensely of a person they have loved or lost, Pagnes began to engrave letters into his chest with a scalpel. Meanwhile, Stenke was on the other side of the room and was repeatedly falling on a slippery floor wetted with oil (Figure 11). It was a truthful moment that the audience silently agreed to share in silence. As if overpassing the intimate suffering that each one was carrying within, they were eventually relieved of it by being together, holding the space for each other, releasing their pain from their hearts to let it flow through their hands on Pagnes's wounded torso (Figure 12). VestAndPage's suffering, bodies and actions are a mere tool to make this catharsis possible. 


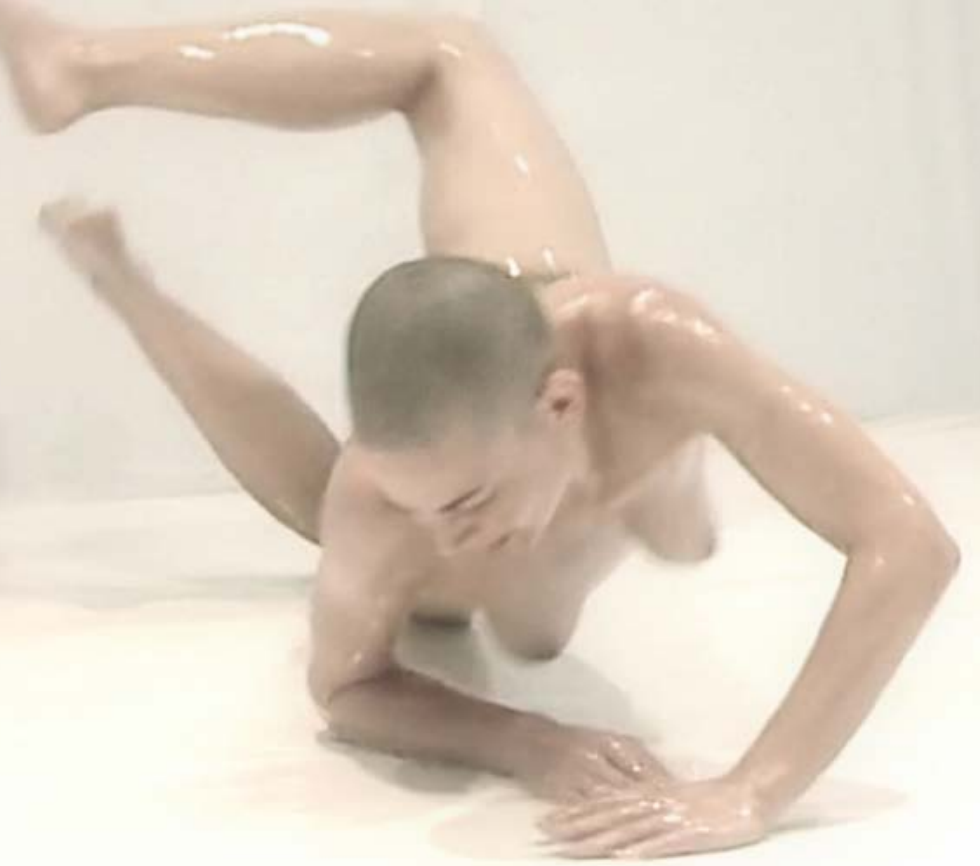

Figure 11 - VestAndPage,

Panta Rhei V: Matter (2012).

Taipei Artist Village, Taipel, ROC

Photograph by LiU Yao.

Figure 12 - VestAndPage,

Panta Rhel V: Matter (2012).

Taipel Artist Village, TaipeI, ROC

Photograph by Liu Yao. 


\section{REFERENCES}

(pseudo-) AVICENNA. Quod sublimatio fit per aliquem de quinque modis. Artis Chemicae Principes, Avicenna atque Geber: Liber Abuali Abincine de anima in arte alchimiae. Edited by Mino Celsi. (Ed.). Basel: Pietro Perna, 1572, XIII, p. 270-277 [p. not numbered + p. 1-471].

BATAILLE, G. Erotism, Death And Sensuality. San Francisco: City Light Books, 1986.

BERNE, E. Transactional Analysis in Psychotherapy: a systematic individual and social psychiatry. New York: Groove Press, 1961.

BLOOM, J. D. A Dictionary of Hallucinations. New York: Springer, 2010.

BURKE, E. Reflections on the Revolution in France. Edited by POCOCK, J. G. A. Indianapolis: Hackett Publishing Company, 1987. First edition published in 1790.

CORINTHIANS. English. In: The English Standard Version of the Holy Bible: Containing the Old and New Testaments with Apocrypha. 2, 7:1 (The Temple of the Living God). Wheaton: Crossway, 2013. Bíblia. A. T.

FREUD, S. The Standard Edition of the Complete Psychological Works of Sigmund Freud (1920). London: Vintage: The Hogarth Press: The Institute Psychoanalysis, 2001. v. 18. First edition published in 1955-[74].

FRIEND, C. Social Contract Theory. The Internet Encyclopedia of Philosophy. 1995. Available in: <https://www.iep.utm.edu/soc-cont/>. Access on: 26 June 2018.

GANS, E. Sacrificing Culture. Chronicle of Love and Resentment, Los Angeles, n. 184, Oct. 1999. Unpaged. Available in: <http://anthropoetics.ucla.edu/views/vw184/>. Access on: 11 March 2005. GIRARD, R. Violence and the Sacred. Baltimore: The Johns Hopkins University Press, 1972. GITTA, S. The German Trauma: Experiences and Reflections, 1938 - 2000. London: Penguin, 2000.

HIRSCHMAN. J. (Ed.). Artaud Anthology. San Francisco: City Light Book, 1965.

LACAN, J. Anxiety: The Seminar of Jacques Lacan, Book X. Edited by Jacques Alain-Miller; Translated by Adrian R. Price, A.R. Cambridge MA: Polity Press, 2014. First edition published in 1962-1963.

LACAN, J. Du Discours Psychanalytique. Lacan in Italia 1953-1978 En Italie Lacan. Edited by G. B. Contri; Transleted by Jack W. Stone Milano: La Salamandra, 1978. p. 32-55. . Columbia, MO: University of Missouri, 2009. p. 1-15. Available on: http://www.mediafire.com/file/ lighz4cgtam3911/19720512+Lacan+Milan_Discourse2.pdf. Access on: 18 Sept. 2018.

LACAN, J. La mort est du domaine de la foi. Conférence à Louvain, 13 October 1972. Unpaged. Available on: http://aejcpp.free.fr/lacan/1972-10-13.htm. Excerpted from: Lacan Parle: Seminar recording (1972), directed by F. Wolff, Original English subtitles.

LACAN, J. Some Reflections on the Ego. International Journal of Psycho-Analysis, London, v. 34, n. 1, p. 11-17,1953. Available on: http://www.lacanianworks.net/?p=5624. 
LACAN, J. The Ethics of Psychoanalysis 1959-1960: The Seminar of Jacques Lacan: Book VII.

Edited by Jacques Alain-Miller; Translated with notes by Dennis Porter. London: Tavistock:

Routledge, 1992.

LACAN, J. The Seminar Of Jacques Lacan, Book XVII: Psychoanalysis upside down/The reverse side of psychoanalysis, 1969-1970. Gallagher, C. transl. Dublin: DBS, 2001. First edition published in 1969-1970. Available on: https://esource.dbs.ie/handle/10788/166. Access on: 10 Feb. 2017.

LEVITICUS. English. In: The English Standard Version of the Holy Bible: Containing the Old and New Testaments with Apocrypha. 17:11, p. 74. 2011. Wheaton: Crossway, 2011. p. 74. Bíblia. A. T.

MACDONALD, G. Social Pain and Hurt Feelings. In: CORR, P. J.; MATTHEWS, G. (Ed.). Cambridge Handbook of Personality Psychology. Cambridge UK: Cambridge University Press, 2009. p. 541-555.

MEERWIJK, E. L.; WEISS S. J. Toward a unifying definition of psychological pain. Journal of Loss \& Trauma, Milton Park UK, v. 16, n. 5, p. 402-412, 2011. Available on: https://doi.org/10.1080/15325 024.2011.572044. Access on: 29 June 2018.

MEIER, A. Walking on Mirrors Until You Bleed, and Other Images from a Performance of Poetic Pain. Hyperallergic, Brooklin NY, 2013. Available on: https://hyperallergic.com/76781/walkingon-mirrors-until-you-bleed-and-other-images-from-a-performance-of-poetic-pain/. Access on: 30 July 2013.

MOUREAU, S. Elixir Atque Fermentum. New Investigations About the Link Between PseudoAvicenna's Alchemical De Anima and Roger Bacon: Alchemical and Medical Doctrines. Traditio, New York, v. 68, p. 277-325, 2013. Available on: 10.1017/S0362152900001689. Access on: 27 June 2018.

NAKKEN, C. The Addictive Personality: Understanding the Addictive Process and Compulsive Behavior. Center City, MN: Hazelden Publishing, 1996.

PAGNES, A. On the Nature of the Image and its Performativity. Venice International Performance Art Week: Hybrid Body - Poetic Body. Venice: VestAndPage Press, 2012. p. 33-54. Exhibition Catalogue.

PERLEMUTTER, D. The Sacrificial Aesthetic: Blood Rituals from Art to Murder. Anthropoetics Journal of Generative Antropology, Los Angeles, v. 5, n. 2, p. 1-10, Fall 1999/ Winter 2000. Available in: <http://anthropoetics.ucla.edu/ap0502/blood/>. Access on: 21 June 2018. PETERLINI, P. Riflessioni sulla pratica del cutting. Attualità Lacaniana, Roma, n. 17, p. 173-180, July/Dec. 2013.

PETERLINI, P. Lo squartamento estetico. La distruzione della bellezza Body Art. In: MIEROLO, A.; RODRIGUEZ, M. T. (Ed.). Il disagio della bellezza. Milano: Franco Angeli, 2006. p. 115-119.

RICHARDSON, M. Georges Bataille: Essential Writings. London: Sage, 1998.

SABBATUCCI, D. Mortification. In: ELIADE, M. (Ed.). The Encyclopedia of Religion. New York: Macmillan Publishing, 1987. p. 113-115. v. X.

SARTRE, J. P. Being and Nothingness. New York: Philosophical Library, 1956. French Originally published: Paris: Gallimard, 1943.

SCARRY, E. The Body in Pain: the making and unmaking of the world. New York: Oxford University Press, 1985. 
SCHEFF, T. J. Catharsis in Healing, Ritual and Drama. Berkeley: University of California Press, 1979.

SHNEIDMAN, E. S. The Suicidal Mind. Oxford: Oxford University Press, 1996.

SVOLOS, T. Introducing the 'New Symptoms.' In: BALDWIN, Y. G.; MALONE, K.; SVOLOS, T. (Ed.). Lacan and Addiction: An Anthology. London: Karnac Books, 2011. p. 75-88.

VANDENBOS, G. R. (Ed.). APA Dictionary of Clinical Psychology. Washington DC: American Psychological Association, 2013 [2007].

VESTANDPAGE. VestAndPage interviewed on Pain and Suffering. [Personal message]. Email received by <Amber Rose Ellis> 24 February 2018a.

VESTANDPAGE. VestAndPage interviewed on Pain and Suffering. [Skype conversation]. Skype conversation with <Felipe Henrique Monteiro Oliveira> 12 March 2017; 28 March 2017; 27 April 2017; 16 June 2018b.

WILLIE, R. S. G. On the Capacity to Endure Psychic Pain. Scandinavian Psychoanalytic Review, Milton Park UK, v. 34, n. 1, p. 23-30, 2011.

Andrea Pagnes (VestAndPage): VestAndPage (Andrea Pagnes and Verena Stenke) performance practice is contextual, conceived psycho-geographically in response to social situations, natural and historical surroundings. They explore pain sublimation, suffering, fragility, risk-taking, trust in change, union and endurance to merge from reality poetic elements to contrast the exercise of power and discrimination. Conceivers and curators of art community projects and of the Venice International Performance Art Week since its inception, they won the best movie award at the Berlin Independent Film Festival (2018) with their last performance-based film Plantain.

Felipe Henrique Monteiro Oliveira: PhD in Performing arts (Federal University of Bahia), he is a writer and performance artist specialised on 'differentiated bodies in performance,' author of the books Corpos Diferenciados em performance (2018), and Corpos diferenciados: A Criação da performance Kahlo em mim eu e(m) Kahlo (2013).

Amber Rose Ellis: MA in Performance (Liverpool Hope University, UK), she researches on connection with another/the other through a subject matter that makes one feel isolated, to demonstrate how art can transcend words and transform pain and suffering into interpersonal relations while breaking down exterior stigmas.

Aisha Ryannon Pagnes: is sound media artist at the faculty of art \& science at the KABK - Royal Academy of Art (The Hague, NL). Emotional relational intelligence, creative thinking and sensory perception are the main fields of her artistic and philosophical research. 